\title{
Aleksander Szpojankowski
}

\section{Klaster jako umowa nienazwana}

Rosnące nakłady na badania i rozwój wymuszają na przedsiębiorcach odnalezienie nowych form współpracy. W ostatnim okresie w Polsce na popularności zyskuje zastosowanie znanej już W gospodarkach rozwiniętych konstrukcji klastra. Artykuł porusza problematykę funkcjonowania klastra opartego o umowę nienazwaną, ze szczególnym uwzględnieniem problemów, jakie mogą wyniknąć $\mathrm{z}$ korzystania $\mathrm{z}$ nieuregulowanej formy prawnej, dotyczących przede wszystkim odpowiedzialności cywilnej, zagadnień podatkowych oraz prawa antymonopolowego. We wnioskach porusza się propozycję uregulowania umowy klastra w przepisach powszechnie obowiązujących.

\section{Wstęp}

Dynamiczny rozwój projektów technologicznych wymusza na przedsiębiorcach coraz to nowe formy kooperacji w celu zmniejszenia ponoszonych kosztów wynikających z wysokonakładowych inwestycji, przyspieszenia procesu transferu technologii i wiedzy pomiędzy jednostkami naukowymi i przedsiębiorcami, a co za tym idzie, zwiększenia konkurencyjności na rynku zarówno krajowym, jak i międzynarodowym. Jedną z wielu dostępnych dla przedsiębiorców form współpracy jest klaster. Według danych Polskiej Agencji Rozwoju Przedsiębiorczości do końca 2015 roku w Polsce powstały 134 klastry, w których łącznie działa 5868 podmiotów ${ }^{1}$.

Z uwagi na rosnącą skalę zjawiska warto w pierwszej kolejności przyjrzeć się czym klaster jest, w jaki sposób został on uregulowany w polskim systemie prawnym oraz w jakich formach prawnych jest on prowadzony. Wobec braku odnoszącej się wprost do tej instytucji regulacji prawnej, w dalszej kolejności należy przeanalizować konstrukcję umowy klastra W świetle swobody kontraktowania uregulowanej w Kodeksie cywilnym ${ }^{2}$. Wreszcie, celowym będzie wskazanie na możliwe zagrożenia i ograniczenia wynikające z prawa ochrony konkurencji oraz prawa podatkowego. We wnioskach z analizy umowy

\footnotetext{
${ }^{1}$ G. Buczyńska, D. Frączak, P. Kryjom, Raport z inwentaryzacji klastrów w Polsce 2015, Warszawa 2016, s. 7, źródło:

http://pi.gov.pl/PARPFiles/media/_multimedia/C1E1B3DE727F45C0990A2F06D8102839/20160308_152251\% 20Raport_z_inwentaryzacji_klastrow_w_Polsce_2015.pdf. [dostęp: 4.5.2017].

${ }^{2}$ Ustawa z 23.4.1964 r. - Kodeks cywilny, t.j. Dz.U. z 2017 r. poz. 459 z późn. zm., dalej jako k.c.
} 
klastra należy rozważyć czy należałoby uregulować umowę klastra w prawie powszechnie obowiązującym.

\section{Pojęcie klastra}

Słowo „klaster” wywodzi się z angielskiego słowa cluster, co oznacza „grono” lub „kiść”. Pojęcie to zostało zdefiniowane na potrzeby nauk ekonomicznych przez amerykańskiego ekonomistę Michaela Portera jako ,geograficzne skupiska wzajemnie powiązanych firm, wyspecjalizowanych dostawców, jednostek świadczących usługi, firm działających w pokrewnych sektorach i związanych z nimi instytucji (na przykład uniwersytetów, jednostek normalizacyjnych i stowarzyszeń branżowych) w poszczególnych dziedzinach, konkurujących między sobą, ale także współpracujących" 3 . Przytoczona definicja jedynie opisuje to, czym klaster jest, czyli skupiskiem współpracujących ze sobą przedsiębiorców wraz z zapleczem intelektualnym oraz infrastrukturalnym. Możemy na jej podstawie wyróżnić co najmniej trzy kategorie podmiotów będącymi stronami umowy klastra. Są to: przedsiębiorcy, instytucje naukowe (np. uniwersytety lub instytuty badawcze) oraz usługodawcy dostarczający podstawowych usług na rzecz przedsiębiorców zrzeszonych w klastrze.

Definicja Portera, z uwagi na swoją specyfikę, a konkretnie jej zastosowanie na potrzeby nauk ekonomicznych, nie wyczerpuje problematyki niniejszego artykułu. Niezbędne jest posłużenie się dwiema definicjami sformułowanymi w polskim prawie.

Pierwszą z nich jest ta wynikająca z §14a ust. 4 Rozporządzenia Ministra Gospodarki z 2.12.2006 r. w sprawie udzielania przez Polską Agencję Rozwoju Przedsiębiorczości pomocy finansowej niezwiązanej z programami operacyjnymi ${ }^{4}$. Stwierdza ona, że „przez klaster rozumie się przestrzenną i sektorową koncentrację podmiotów działających na rzecz rozwoju gospodarczego lub innowacyjności oraz co najmniej dziesięciu przedsiębiorców, wykonujących działalność gospodarczą na terenie jednego lub kilku sąsiednich województw, konkurujących i współpracujących w tych samych lub pokrewnych branżach oraz powiązanych rozbudowaną siecią relacji o formalnym i nieformalnym charakterze, przy czym co najmniej połowę podmiotów funkcjonujących w ramach klastra stanowią przedsiębiorcy". Ustęp 5 komentowanego przepisu definiuje podmioty, które mogą być

\footnotetext{
${ }^{3}$ M. Porter, Porter o konkurencji, Warszawa 2001, s. 246.

${ }^{4}$ Dz.U. Nr 226 poz. 1651, dalej jako Rozporządzenie PARP.
} 
koordynatorami klastra. Są to: fundacje, stowarzyszenia rejestrowe, spółki akcyjne, spółki z ograniczoną odpowiedzialnością oraz organizacje zrzeszające przedsiębiorców.

Kolejną definicją jest ta ujęta w $\S 2$ pkt 8 Rozporządzenia Ministra Rozwoju Regionalnego z 1.4.2009 r. w sprawie udzielania przez Polską Agencję Rozwoju Przedsiębiorczości pomocy finansowej na promocję gospodarczą Polski Wschodniej, stworzenie sieci współpracy centrów obsługi inwestora, tworzenie i rozwój klastrów, tworzenie polityki rozwoju regionalnego w ramach Programu Operacyjnego Rozwój Polski Wschodniej 2007-20135 , która brzmi: „(...) klastrze - należy przez to rozumieć przestrzenną i sektorową koncentrację podmiotów działających na rzecz rozwoju gospodarczego lub podmiotów działających na rzecz innowacyjności, jednostek naukowych, o których mowa w $\S 1$ ust. 2 pkt 3, oraz przedsiębiorców wykonujących działalność gospodarczą na terenie jednego lub kilku sąsiadujących województw Polski Wschodniej, konkurujących i współpracujących w tych samych lub pokrewnych branżach oraz powiązanych siecią współpracy".

Pomiędzy obiema definicjami zachodzą poważne rozbieżności dotyczące powstania klastra. Według pierwszej z nich do powstania klastra potrzebne jest minimum dziesięć podmiotów, z czego połowę muszą stanowić przedsiębiorcy. W drugim przypadku wymóg ilościowy nie istnieje; definicja mówi wyłącznie o przestrzennej i sektorowej koncentracji podmiotów, co powoduje, że klaster mógłby zostać założony przez tylko dwa lub trzy podmioty.

Obie zostały ujęte w aktach prawnych rangi rozporządzenia, a zatem mimo charakteru prawa powszechnie obowiązującego, mogą odnosić się tylko do sytuacji określonych w rozporządzeniu i mają ograniczone zastosowanie ${ }^{6}$.

Pojęcie klastra energii definiowane jest w art. 2 pkt 15a ustawy o odnawialnych źródłach energii ${ }^{7}$, jako „,cywilnoprawne porozumienie, w skład którego mogą wchodzić osoby fizyczne, osoby prawne, jednostki naukowe, instytuty badawcze lub jednostki samorządu terytorialnego, dotyczące wytwarzania i równoważenia zapotrzebowania, dystrybucji lub obrotu energią $\mathrm{z}$ odnawialnych źródeł energii lub $\mathrm{z}$ innych źródeł lub paliw, w ramach sieci dystrybucyjnej o napięciu znamionowym niższym niż $110 \mathrm{kV}$, na obszarze działania tego klastra nieprzekraczającym granic jednego powiatu w rozumieniu ustawy z 5.6.1998 r. o samorządzie powiatowym (Dz.U. z 2016 r. poz. 814) lub 5 gmin w rozumieniu

\footnotetext{
${ }^{5}$ T.j. Dz.U.z 2013 r., poz. 708.

${ }^{6}$ Por. L. Garlicki, Polskie prawo konstytucyjne. Zarys wyktadu, Warszawa 2014, s. 134.

${ }^{7}$ Ustawa z 20.2.2015 r. o odnawialnych źródłach energii, Dz.U. z 2015 r. poz. 478.
} 
ustawy z 8.3.1990 r. o samorządzie gminnym (Dz.U. z 2016 r. poz. 446); klaster energii reprezentuje koordynator, którym jest powołana w tym celu spółdzielnia, stowarzyszenie, fundacja lub wskazany w porozumieniu cywilnoprawnym dowolny członek klastra energii”". Jej przydatność także jest ograniczona skoro wyjaśnia pojęcie węższe od pojęcia „klastra”, jakim jest „,klaster energii”.

Żadna z przytoczonych definicji nie może być uznana za regulację klastra jako umowy nazwanej, jednak niektóre elementy przytoczonych regulacji mogą pomóc w stworzeniu wzorca takiej umowy jako umowy emiprycznej.

Treść cytowanych regulacji skłania do przyjęcia poglądu, że klastrem jest koncentracja powiązanych podmiotów gospodarczych prowadzących działalność w tych samych lub pokrewnych branżach oraz podmiotów świadczących usługi na rzecz tychże podmiotów gospodarczych oraz jednostek o charakterze naukowym. Warto zwrócić uwagę, że warunkiem koniecznym umowy klastra jest wielość podmiotów oraz ich powiązanie branżowe, tak aby współpraca wewnątrz klastra przynosiła jak największe korzyści wszystkim stronom.

\section{Formy prawne istnienia klastra}

Choć Rozporządzenie PARP formułuje zamknięty katalog form prawnych, w jakich mogą funkcjonować koordynatorzy klastra w wymieniając: fundację, stowarzyszenie rejestrowe, spółkę akcyjną, spółkę z ograniczoną odpowiedzialnością oraz organizacje zrzeszające przedsiębiorców, wyliczenie to stanowi jedynie wymóg dofinansowania klastra przez Polską Agencję Rozwoju Przedsiębiorczości i znajduje zastosowanie wyłącznie na gruncie rozporządzenia.

W literaturze przedmiotu podnosi się, że klaster może przybierać również inną formę prawną, między innymi być prowadzony $\mathrm{W}$ formie spółki prawa handlowego czy skonstruowany za pomocą umowy cywilnoprawnej ${ }^{8}$. Równie często rozważaną formą prawną dla klastra jest spółdzielnia ${ }^{9}$.

\footnotetext{
${ }^{8}$ P. Malinowski (w:), Uwarunkowania i możliwości rozwoju klastrów i inicjatyw klastrowych $w$ województwie opolskim. Ocena ekspercka, red. W. Duczmal, W. Potwora, Opole 2011, s. 28-29, źródło: https://www.efs.20072013.gov.pl/analizyraportypodsumowania/baza_projektow_badawczych_efs/documents/3_uwarunkowania_i_m ozliwosci_rozwoju_klastrow_i_inicjatyw_klastrowych.pdf [dostęp: 4.5.2017].

${ }^{9}$ K. Cupryś, Klaster - sposób na lepsza wspótprace przedsiębiorstw, „Przegląd Piekarski i Cukierniczy”, luty 2009, s. 6-12, źródło: http://www.pobiarzyn.nazwa.pl/klaster/files/about_us/1238270487.pdf [dostęp: 4.5.2017].
} 


\section{Klaster jako umowa nienazwana}

Umowa nienazwana to taki rodzaj kontraktu, który nie został przez ustawodawcę uregulowany $\mathrm{w}$ żadnym akcie prawnym. Taki stosunek prawny oparty jest o swobodę kontraktowania uregulowaną w art. $353^{1}$ k.c. ${ }^{10}$, z odnoszącymi się także do umowy klastra ograniczeniami dowolności kształtowania stosunku umownego (właściwość stosunku zobowiązaniowego, przepisy ustawy oraz zasady współżycia społecznego) ${ }^{11}$. Ich naruszenie, przy zastrzeżeniu konieczności dochowania wymaganej formy prawnej danej czynności, skutkować będzie sankcją bezwzględnej nieważności umowy sprzecznej $\mathrm{z}$ ustawą, przewidzianą w art. 58 k.c. ${ }^{12}$.

Jak zostało zaznaczone, celem utworzenia klastra jest organizacja współpracy wielu podmiotów z określonej branży i zwiększenie konkurencyjności całego sektora. Chodzi o stworzenie tak zwanego efektu synergii, czyli wytworzenie efektu poprzez współdziałanie wielu czynników, który jest większy od sumy oddziaływania poszczególnych czynników ${ }^{13}$.

Dla realizacji tego założenia sama umowa klastra powinna zawierać postanowienia, które umożliwiłyby efektywną realizację celów działania klastra. Dlatego wśród podstawowych elementów umowy klastra należy wyróżnić przede wszystkim, poza stronami umowy, cele, jakie strony chcą osiągnąć poprzez zawiązanie klastra oraz sposoby ich realizacji, sposób finansowania klastra, stworzenie organów oraz określenie ich kompetencji, prawa i obowiązki stron, odpowiedzialność za niedotrzymanie postanowień umownych, sposoby dołączenia i opuszczenia klastra, sposób rozwiązania umowy ${ }^{14}$.

\footnotetext{
${ }^{10}$ Przepis ten, będący odzwierciedleniem art. 55 Rozporządzenia Prezydenta Rzeczpospolitej z 27.10.1933 r. Kodeks Zobowiązań (Dz.U. Nr 82, poz. 598 z późn. zm.) powrócił do polskiego systemu prawnego dzięki nowelizacji k.c. z 28.7.1990 r. (Dz.U. Nr 55 poz. 321).

${ }^{11}$ Por. T. Wiśniewski, Komentarz do kodeksu cywilnego. Księga trzecia. Zobowiazania. Tom 1, Warszawa 2011, s. 21. Z. Rawański, A. Olejniczak, Zobowiązania - część ogólna, Warszawa 2014, s. 135; A. Olejniczak (w:) Kodeks cywilny. Komentarz. Tom III. Zobowiazania. Część ogólna, red. A. Kidyba, Warszawa 2014, s. 45; P. Machnikowski (w:) Kodeks cywilny. Komentarz, red. E. Gniewek, P. Machnikowski, Warszawa 2014, s. 604.

${ }^{12}$ Z. Radwański, A. Olejniczak, op. cit., s. 137.

${ }^{13}$ D. Ćwik, Analiza prawna możliwości działania klastra turystycznego, Warszawa 2016, s. 2, źródło: https://zarabiajnaturystyce.pl/dobre-praktyki/com-k2/baza-wiedzy/seminarium-warsztatowe-polskiejorganizacji-turystycznej-i-ministerstwa-sportu-iturystyki?highlight=WyJhbmFsaXphIiwicHJhd25cdTAxMDUiLCJtb1x1MDE3Y2xpd29cdTAxNWJjaSIsImR6 aWFcdTAxNDJhbmlhIiwia2xhc3RyYSIsInR1cnlzdHljem51Z28iLCJhbmFsaXphIHByYXduYSIsImFuYWxpe mEgcHJhd25hIG1vXHUwMTdjbG13b1x1MDE1YmNpIiwicHJhd25hIG1vXHUwMTdjbG13b1x1MDE1YmNpI iwicHJhd25hIG1vXHUwMTdjbG13b1x1MDE1YmNpIGR6aWFcdTAxNDJhbmlhliwibW9cdTAxN2NsaXdvX HUwMTViY2kgZHppYVx1MDE0MmFuaWEiLCJtb1x1MDE3Y2xpd29cdTAxNWJjaSBkemlhXHUwMTQy YW5pYSBrbGFzdHJhIiwiZHppYVx1MDE0MmFuaWEga2xhc3RyYSIsImR6aWFcdTAxNDJhbmlhIGtsYXN 0cmEgdHVyeXN0eWN6bmVnbyIsImtsYXN0cmEgdHVyeXN0eWN6bmVnbyJd [dostęp: 5.5.2017].

${ }^{14}$ Ekspertyza Ministerstwa Energii, Koncepcja funkcjonowania klastrów energii w Polsce, Warszawa 2017, s. 151 , 
Jeżeli strony zawiązujące klaster zamierzają ubiegać się o dotacje publiczne (krajowe, wspólnotowe), należy w umowie przewidzieć powołanie koordynatora klastra, w jednej z form przewidzianych $§ 14$ a ust. 5 Rozporządzenia PARP.

Ukazanie „modelowej” konstrukcji umowy klastra i precyzyjne określenie jej postanowień umownych nie jest w pełni możliwe, skoro ich treść uzależniona jest między innymi od sektora, w którym działa klaster, czy celów, jakie zakładają podmioty zawierające konkretną umowę. Niemniej większość umów klastrowych zawiera analogiczne postanowienia odnoszące się do sposobu zarządzania klastrem.

Z dostępnych publicznie umów klastrowych wynika, że na podstawie umowy klastra tworzone są dwa quasi organy, powoływane do bieżącego zarządzania klastrem. Są to Rada Klastra (czasem Zgromadzenie Członków Klastra), zbliżona konstrukcyjnie do zgromadzenia wspólników w spółce z ograniczoną odpowiedzialnością oraz Zarząd lub Prezydium Klastra (zbliżona do zarządu w spółkach kapitałowych) ${ }^{15}$. Do kompetencji Rady Klastra należy wyznaczanie kierunków i strategii rozwoju klastra, sprawowanie nadzoru nad działalnością klastra, przyjmowanie rocznych sprawozdań z działalności, ustalanie wysokości opłaty członkowskiej, wybieranie członków Zarządu. W skład Rady Klastra wchodzą przedstawiciele wszystkich członków klastra. Z kolei Zarząd Klastra dysponuje uprawnieniami do przyjmowania i skreślania bądź wykluczania członków klastra, uchwalania budżetu, sporządzenia sprawozdania z działalności klastra, stworzenia zasad funkcjonowania i koordynowania prac biura klastra, opracowywanie planów działania i tworzenie grup projektowych, prowadzenie rejestru członków, przechowywania protokołów z posiedzeń Rady, czy wreszcie ustalanie wysokości składek członkowskich.

\section{Korzyści i ryzyka płynące z ujęcia klastra jako umowy nienazwanej}

Powołanie klastra na mocy umowy nienazwanej wydaje się korzystnym rozwiązaniem dla przedsiębiorców chcących wykorzystać tę formę kooperacji. Wynika to, po pierwsze, z wysokiego stopnia odformalizowania takiej umowy, w związku z czym nie ma potrzeby ponoszenia dodatkowych kosztów związanych z zawiązaniem klastra, po drugie daje stronom szeroką autonomię do dowolnego kształtowania praw i obowiązków członków oraz celów

http://www.me.gov.pl/files/upload/23203/Koncepcja_funkcjonowania_klastrow_energii_PL_2017.pdf [dostęp: 5.05.2017].

15 Źródła przykładowych umów: http://www.pke.org.pl/umowa-klastra/ http://lifescience.pl/o-klastrzelifescience/archiwum/raporty-roczne-2/umowa-klastra-lifescience/ http://btmmazowsze.pl/files/UmowaKlastra.pdf http://klasterlignum.pl/pliki/Umowa_Klaster.pdf [dostęp: 5.5.2017]. 
klastra, tak aby w sposób jak najkorzystniejszy dla nich wykorzystać korzyści płynące z takiego rodzaju współpracy.

Niestety, oparcie umowy klastra umowy wyłącznie o zasadę swobody umów niesie za sobą także pewne ryzyka.

\subsection{Brak osobowości prawnej}

Pierwsze $\mathrm{z}$ nich związane jest $\mathrm{z}$ brakiem osobowości prawnej klastra i odpowiedzialności cywilnoprawnej członków klastra za jego zobowiązania. Odmiennie niż spółki kapitałowe, klaster nie ma osobowości prawnej, ani nawet, jak spółki osobowe, zdolności prawnej. Brak zdolności prawnej i zdolności do czynności prawnych oraz - w konsekwencji - zdolności sądowej i procesowej jest wyraźnym mankamentem tej formy kooperacji. Oznacza, że klaster nie jest podmiotem praw i obowiązków w stosunkach cywilnoprawnych ${ }^{16}$. Takie rozwiązanie może stanowić poważną przeszkodę $\mathrm{w}$ bieżącym funkcjonowaniu klastra na rynku, ponieważ nie może on być stroną relacji cywilnoprawnych. W kwestii odpowiedzialności powstaje sytuacja zbliżona do konstrukcji konsorcjum ${ }^{17}$, a zatem za wszelkie zobowiązania wynikające z realizacji umowy klastra będą odpowiadać jego członkowie. Taką interpretację potwierdza Sąd Najwyższy, który w postanowieniu z 27.5.2010 r. stwierdził, że „konsorcjum nie posiada podmiotowości prawnej, a tym samym nie posiada zdolności sądowej. Stroną w znaczeniu procesowym są więc oba podmioty wchodzące w skład konsorcjum ${ }^{18}$."

Dlatego wartym rozważenia jest powołanie w umowie tzw. koordynatora klastra, który będzie pełnił funkcje związane $\mathrm{z}$ reprezentacją klastra - w istocie stron umowy klastra oraz składania i przyjmowania w jego imieniu - to znaczy w imieniu stron umowy klastra oświadczeń woli. Odwołując się do definicji koordynatora klastra z Rozporządzenia PARP, wskazać należy, że może nim być podmiot prowadzony $\mathrm{w}$ jednej $\mathrm{z}$ wymienionych $\mathrm{w}$ przepisie form prawnych oraz podstawowym przedmiotem jego działalności ma być realizacja przedsięwzięć na rzecz przedsiębiorców oraz na rzecz współpracy przedsiębiorców z jednostkami naukowymi, szkołami wyższymi oraz organami administracji samorządowej. Z przepisu nie wynika, czy koordynatorem klastra może być jeden z podmiotów zakładających klaster spełniający powyższe wymagania,

\footnotetext{
${ }^{16}$ J. Frąckowiak (w:) System Prawa Prywatnego. Tom 1, M. Safjan (red.), Warszawa 2012, s. 1141.

${ }^{17}$ P. Malinowski, op. cit., s. 30.

${ }^{18}$ Postanowienie Sądu Najwyższego z 27.5.2010 r., III CZP 25/10, Legalis.
} 
czy też ma to być nowy podmiot, powołany w tym celu na mocy umowy klastra. Wydaje się, że skoro ustawodawca nie wyłączył żadnej z tych możliwości, obie mogą zostać zastosowane w praktyce. Przyznanie jednemu z członków klastra uprawnień koordynatora wydaje się być jednak niekorzystne dla innych członków klastra, ponieważ tym sposobem podmiot ten uzyska bardzo szerokie uprawnienia w zakresie zarządzania klastrem (np. wynikające z reprezentacji czy otrzymywania dotacji). Z tej perspektywy korzystniejszym rozwiązaniem wydaje się powołanie przez członków klastra nowego podmiotu, który z ich udziałem będzie pełnił tę funkcję. Dzięki temu żaden $\mathrm{z}$ członków klastra nie uzyska nadmiernego uprzywilejowania względem innych, a sam proces zarządzania będzie bardziej przejrzysty.

\subsection{Ryzyko podatkowe}

Z brakiem zdolności prawnej klastra nierozerwalnie wiąże się ryzyko podatkowe związane z przepływami finansowymi pomiędzy członkami klastra a samym klastrem. Nie posiadając prawnej podmiotowości klaster nie jest uznawany przez ustawodawcę i organy podatkowe za podatnika. Wszelkie obowiązki podatkowe będą ciążyć zatem na członkach klastra $^{19}$. Sytuacja taka może poddawać w wątpliwość właściwy sposób rozliczania finansowania klastra. De lege lata warto posiłkować się instytucją koordynatora klastra, dzięki czemu powstanie jeden podmiot, który w sposób przejrzysty będzie mógł rozliczać środki finansowe przepływające wewnątrz klastra. Ponadto organy podatkowe pozwalają koordynatorom klastrów zakwalifikować wydatki poczynione w ramach pełnionej funkcji jako koszty uzyskania przychodu, obniżając tym samym podstawę opodatkowania ${ }^{20}$.

\subsection{Ryzyko związane z zakłóceniem konkurencji}

Klaster w swojej idei jest pewnego rodzaju koncentracją przedsiębiorców, którzy współpracując ze sobą chcą zwiększyć swoją konkurencyjność względem innych podmiotów obecnych na rynku. Jasnym jest jednak, że nie każda forma koncentracji przedsiębiorców jest dopuszczalna, skoro może w sposób sprzeczny z prawem naruszać

\footnotetext{
${ }^{19}$ P. Malinowski, op. cit., s. 30.

${ }^{20}$ Interpretacja indywidualna z 13.1.2017 r., 1462-IPPB3.4510.1071.2016.1.PS, Legalis.
} 
zasady konkurencji. Tę sytuację regulują w polskim systemie prawnym przepisy unijne ${ }^{21}$ i ustawa o ochronie konkurencji i konsumentów ${ }^{22}$.

W u.o.k.k. kwestię zakazanych porozumień reguluje art. 6, który definiuje je jako „,zakazane są porozumienia, których celem lub skutkiem jest wyeliminowanie, ograniczenie lub naruszenie w inny sposób konkurencji na rynku właściwym (...)” i wymienia katalog przykładowych porozumień. Zgodnie $\mathrm{z}$ art. 4 pkt. 5 komentowanej ustawy, porozumieniami są:

- umowy zawierane między przedsiębiorcami, między związkami przedsiębiorców oraz między przedsiębiorcami i ich związkami albo niektóre postanowienia tych umów,

- uzgodnienia dokonane $\mathrm{w}$ jakiejkolwiek formie przez dwóch lub więcej przedsiębiorców lub ich związki,

- uchwały lub inne akty związków przedsiębiorców lub ich organów statutowych.

Czy klaster może zostać uznany za porozumienie w rozumieniu u.o.k.k. zależy od postanowień konkretnej umowy i ujętej w niej możliwej współpracy horyzontalnej pomiędzy przedsiębiorcami (w której udział biorą podmioty na tym samym szczeblu obrotu gospodarczego ${ }^{23}$ ). Stanie się tak, jeżeli umowa klastra przewidywać będzie choćby jedną z trzech form przewidzianych w art. 6 u.o.k.k. i wyeliminuje konkurencję w danym sektorze rynku, ograniczy ją lub naruszy w inny sposób ${ }^{24}$. Warto mieć na względzie, że przy dokonywaniu analizy porozumienia należy odwołać się do przepisów odnoszących się do oświadczeń woli w k.c. ${ }^{25}$ i nawet umowy obarczone wadami oświadczenia woli bądź zawarte z niedochowaniem właściwej formy prawnej mogą zostać uznane za uzgodnienia faktyczne i porozumienia ${ }^{26}$. Ratio legis szerokiej definicji „porozumienia” jest bowiem chęć objęcia przez ustawodawcę zakazem z art. 6 u.o.k.k. możliwie wielu form współdziałania przedsiębiorców ${ }^{27}$.

\footnotetext{
${ }^{21}$ Tytuł VII Traktatu o funkcjonowaniu Unii Europejskiej (Wersja skonsolidowana) z 26.10.2012 r., Dz.Urz.UE. $\mathrm{Nr} C 326 / 47$.

${ }^{22}$ Ustawa z 16.2.2007 r. o ochronie konkurencji i konsumentów, Dz.U. z 2007 r., Nr 50, poz. 331 z późn. zm., dalej jako u.o.k.k.

${ }^{23}$ A. Jurowska, op. cit., s. 371.

${ }^{24}$ K. Kohutek (w:) Ustawa o ochronie konkurencji. Komentarz, K. Kohutek, M. Sieradzka, Warszawa 2008, s. $249-250$.

${ }^{25}$ A. Jurkowska (w:) Ustawa o ochronie konkurencji i konsumentów, red. T. Skoczny, Warszawa 2009, s. 164.

${ }^{26}$ Ibidem.

${ }^{27}$ K. Róziewicz - Ładoń, Postępowanie przez Prezesem Urzędu Ochrony Konkurencji i Konsumentów $w$ zakresie przeciw działania praktykom ograniczajacym konkurencje, Warszawa 2011, s. 50.
} 
Ocena wystąpienia takiego przypadku jest w przypadku klastra trudna o tyle, że ustalenie, czy dana umowa zagraża konkurencji, nie opiera się na obiektywnych przesłankach, jak choćby wielkość obrotów, czy udział w rynku ${ }^{28}$.

Zastrzeżenia wymaga, że umowy klastra, zgodnie z art. 13 u.o.k.k., nie wymagają zgłoszenia do UOKiK, ponieważ takiemu obowiązkowi podlega zamiar koncentracji przedsiębiorców poprzez utworzenie nowego przedsiębiorcy, przejęcia lub nabycia części mienia innego przedsiębiorcy.

Dla złagodzenia opisywanego ryzyka w zawieranych umowach klastrowych pojawiają się postanowienia umowne przewidujące, że członkowie klastra nie będą podejmować działań dotyczących koordynacji działań rynkowych ani dokonywać wymiany informacji jeżeli dążyłoby to do naruszenia norm przewidzianych prawem antymonopolowym ${ }^{29}$.

\section{Podsumowanie}

Klastry zaczęły pojawiać się stosunkowo wcześnie, bo w latach 20 i $30 \mathrm{XX}$ wieku. Najlepszymi przykładami są Dolina Krzemowa oraz Hollywood w Kalifornii w Stanach Zjednoczonych ${ }^{30}$. Pokazują one wyraźnie, że kooperacja przedsiębiorców w dość luźnej formie współpracy, jaką jest klaster, przynosi pozytywne efekty. Spowodowane jest to również tym, że klastry nie są ,zamknięte” na przedsiębiorców, w ich skład często wchodzą również instytucje naukowe, co znacząco przyspiesza komercjalizację wyników badań oraz transfer wiedzy do podmiotów rynkowych.

Klaster może być więc wartościową formą zwiększania konkurencyjności przedsiębiorstw $\mathrm{z}$ jednej gałęzi przemysłu rozlokowanych na niewielkim terenie. Również na polskim rynku zauważalny jest trend do zacieśniania współpracy między przedsiębiorcami. Mimo wykorzystania tej formy kooperacji w praktyce, ustawodawca nie zdecydował się dotychczas na odrębne ujęcie normatywne umowy klastra. Sytuacja ta ma swoje dobre i złe strony. Do zalet „nieuregulowania” instytucji klastra należy zaliczyć dużą elastyczność, z jaką założyciele klastra mogą określać swoje prawa i obowiązki, aby czerpać ze współpracy jak największe korzyści oraz odformalizowanie tej struktury,

\footnotetext{
${ }^{28}$ A. Stefanowicz-Barańska, P. Ciupa, Utworzenie niektórych klastrów trzeba zglosić, „Rzeczpospolita” z 27.11.2007 r., źródło: http://www.rp.pl/artykul/72124-Utworzenie-niektorych-klastrow-trzeba-zglosic.html\#ap-1 [dostęp: 6.5.2017].

${ }^{29} \mathrm{~Np}$. umowa klastra Polskiego Klastra Edukacyjnego, źródło: http://www.pke.org.pl/umowa-klastra/ [dostęp: 6.5.2017].

${ }^{30}$ A. Kurczewska (w:) B. Mikołajczyk, A. Kurczewska, J. Fila, Klastry na świecie. Studium przypadków, Warszawa 2009, s. 122.
} 
co znacząco przyspiesza jej tworzenie. Do mankamentów obecnej sytuacji należy brak odrębnej od członków podmiotowości prawnej klastra, która niesie za sobą brak autonomii i szybkości w działaniu klastra na rynku oraz brak pewności podatkowej. Kolejnym problemem jest niejasna sytuacja związana z prawem antymonopolowym.

Ważąc powyższe należy postulować de lege ferenda regulację umowy klastra poprzez nadanie klastrowi zdolności prawnej, tak, by mógł on podejmować autonomiczne działania na rynku, w interesie swoich członków. Kolejnym krokiem powinno być określenie sytuacji podatkowej tych podmiotów. Rozważyć można także określenie statusu prawnego klastra w prawie antymonopolowym. Przede wszystkim jednak celowe byłoby ustawowe zdefiniowanie klastra.

Z drugiej strony warto zachować tę elastyczność, z jaką założyciele klastra mogą określać jego strukturę, funkcję i cele, ponieważ to oni, a nie ustawodawca, najlepiej wiedzą czego oczekują oraz co chcą osiągnąć poprzez taką formę współpracy. Równie ważne jest, aby przy zawieraniu umowy klastra nie przymuszać jego członków do tworzenia nowej osoby prawnej, która byłaby podmiotem zarządzającym klastrem. W praktycznie wszystkich umowach klastra tworzone są quasi-organy powołane w celu zarządzania i podejmowania decyzji związanych z funkcjonowaniem tej struktury. Od ustawodawcy, jak już wspomniano, należy wymagać jedynie nadania klastrowi osobowości prawnej, tak aby mógł on szybciej i efektywniej realizować swoje cele.

Celem tworzenia przepisów prawa w sytuacji rosnącej popularności danego zjawiska powinno być jedynie ramowe uregulowanie go, rozwiązywanie potencjalnych wątpliwości oraz minimalizacja ryzyka, jakie wiąże się z jego funkcjonowaniem ze strony organów administracji państwowej. Tak też jest w przypadku klastrów. Dlatego słusznie postuluje się jedynie bardzo ograniczone uregulowanie tej umowy tak, by przedsiębiorcy mogli autonomicznie określać zasady wzajemnej kooperacji. 
Cluster as an unnamed contract

\section{Summary}

Rising R \& D expenditures force entrepreneurs to find new forms of collaboration. Recently, in Poland the use of cluster constructions, already known in developed economies is gaining in popularity. This article touches the issue of clustering based on an unnamed contract, with particular emphasis on the problems that may arise from the use of an unsettled legal form, primarily relating to civil liability, tax issues and antitrust law. In conclusions author concerns the idea of the settlement of the cluster contract in the statutory law.

\section{Aleksander Szpojankowski}

Absolwent kierunku prawo na Wydziale Prawa i Administracji Uniwersytetu Kardynała Stefana Wyszyńskiego w Warszawie. Stypendysta programu Erasmus+ na uczelniach Universidad de Castilla - La Mancha w Albacete oraz Universidad de Navarra w Pampelunie (Hiszpania). Były współpracownik Fundacji Forum Obywatelskiego Rozwoju. Pracuje w jednej z warszawskich kancelarii prawnych. 